\title{
Effect of thermal aging on the crystalline structure and mechanical performance of fully bio-based, furan-ester, multiblock copolymers
}

\author{
Magdalena Kwiatkowska ${ }^{1, *)}$, Inez Kowalczyk¹), Anna Szymczyk ${ }^{2)}$, Krzysztof Gorący ${ }^{3)}$ \\ DOI: dx.doi.org/10.14314/polimery.2018.9.3
}

\begin{abstract}
In this study, the effect of thermal aging on the physical transitions, crystalline structure development and the mechanical performance of furan-ester, multiblock copolymers is reported. The materials were synthesized via polycondensation in a melt using 2,5-furandicarboxylic acid (FDCA), 1,3-propanediol (1,3-PD) and dimerized fatty acid diol (FADD). All reagents were plant-derived. The copolymers were characterized by a multiblock structure with randomly distributed poly(trimethylene 2,5-furandicarboxylate) (PTF) and FADD segments and a phase separation forced by the crystallization of the rigid segment. As a consequence, the copolymers revealed elastomeric behavior and a rubbery plateau over a relatively large temperature range and also good processability. However, due to the specific architecture of FDCA - the most important bio-based monomer - the crystallization of the rigid segment was impeded. Differential scanning calorimetry (DSC), wide-angle (WAXS) and small-angle X-ray scattering (SAXS) analyses confirmed a significant development in the crystalline structure due to the thermal treatment. As a consequence, noticeable changes in the mechanical performance of the copolymer samples were observed, which is interesting for potential applications of these new materials.
\end{abstract}

Keywords: 2,5-furandicarboxylic acid, furan-ester copolymers, bio-based polymers, thermal aging.

\section{Wpływ procesu wygrzewania na strukturę krystaliczną i właściwości mechaniczne furano-estrowych kopolimerów multiblokowych $\mathrm{z}$ udziałem monomerów pochodzenia roślinnego}

\begin{abstract}
Streszczenie: Analizowano wpływ procesu wygrzewania na przemiany fizyczne, strukturę krystaliczną oraz właściwości mechaniczne furano-estrowych kopolimerów multiblokowych. Materiały otrzymano metodą polikondensacji $\mathrm{w}$ stanie stopionym $\mathrm{z}$ wykorzystaniem pozyskiwanych $\mathrm{z}$ roślin następujących monomerów: kwasu 2,5-furanodikarboksylowego (FDCA), 1,3-propanodiolu (1,3-PD) oraz diolu dimeryzowanych kwasów tłuszczowych (FADD). Badane kopolimery charakteryzowały się multiblokową strukturą z naprzemiennie rozłożonymi segmentami sztywnymi i giętkimi oraz separacją fazową wymuszoną przez krystalizację segmentów sztywnych. W konsekwencji materiały wykazywały cechy typowe dla elastomerów, plateau elastyczności $w$ dość dużym zakresie temperatury oraz łatwość przetwórstwa. Z powodu specyficznej budowy FDCA - najważniejszego biomonomeru - krystalizacja segmentów sztywnych była jednak wyraźnie utrudniona. Metodami różnicowej kalorymetrii skaningowej (DSC) i rozpraszania promieniowania rentgenowskiego pod dużymi i małymi kątami (WAXS i SAXS) potwierdzono istotne zmiany w strukturze krystalicznej na skutek wygrzewania. Stwierdzono również wpływ wygrzewania na właściwości mechaniczne kopolimerów, co może być interesujące w aspekcie aplikacyjnym materiałów.
\end{abstract}

Słowa kluczowe: kwas 2,5-furanodikarboksylowy, kopolimery furano-estrowe, polimery otrzymane z monomerów pochodzenia roślinnego, proces wygrzewania.

\footnotetext{
1) West Pomeranian University of Technology, Institute of Material Science and Engineering, Piastów 19, 70-310 Szczecin, Poland.

2) West Pomeranian University of Technology, Institute of Physics, Piastów 48, 70-310 Szczecin, Poland.

3) West Pomeranian University of Technology, Polymer Institute, Pułaskiego 10, 70-310 Szczecin, Poland.

*) Author for correspondence; e-mail: magdalena.kwiatkowska@zut.edu.pl
} 
Polyesters containing plant-derived monomers are an interesting group of materials that have been extensively developed over the last few years. This is due to the generally wide range of physical properties of thermoplastic polyesters and, consequently, their very high consumption by various industries. The global trend in searching for more environment-friendly polymer materials, including those that are bio-based and biodegradable, is noticeable by intensified research on the already known and commercialized: poly(lactic acid) (PLA) [1-3], poly(butylene succinate) (PBS) [4-7], poly(butylene adipate-co-terephthalate) (PBAT) [8-11], and polyhydroxyalkanoates (PHAs) [12-15]. Recently, a tremendous increase in research on the synthesis of polyesters and their copolymers based on 2,5-furandicarboxylic acid (FDCA) has been observed. This bio-based monomer belongs to the furfural family and most of the synthesis routes use the conversion of 5-hydroxymethylfurfural (HMF) received from vegetable feedstock-derived: glucose, fructose, xylose or saccharose $[16,17]$. Although FDCA production methods using polysaccharides were patented for the first time in the 1990's [18-22], its application for polymer synthesis was not widely investigated due to a low efficiency of the monomer production and some ethical aspects concerning the utilization of crops for human consumption. Nowadays, many new approaches that are much more effective have been developed including approaches based on the utilization of biomass [23, 24], or even carbon dioxide [25]. FDCA production is also commercialized [26]. The particular interest in this acid lies in its structural similarity to petroleum-based: terephthalic, isophthalic, or adipic diacids, among others, and it is considered a green substitute for these important monomers. That explains a multiplicity of research on the synthesis of FDCA-based polyurethanes $[27,28]$, polyamides [29-31], and especially polyesters as counterparts of highly industrially relevant: poly(ethylene terephthalate) PET, poly(butylene terephthalate) PBT and poly(trimethylene terephthalate) PTT [32-38].

In general, furan polyesters reveal about $40-50{ }^{\circ} \mathrm{C}$ lower melting points compared to those based on terephthalic acid. However, their glass transition temperatures are slightly higher [poly(ethylene 2,5-furanoate) PEF, and poly(trimethylene 2,5-furandicarboxylate) PTF], or comparable [poly(butylene 2,5-furanoate) PBF]. The new materials are also characterized by a relatively high tensile strength up to $85 \mathrm{MPa}$ and an $E$ modulus of $c a$. $2800 \mathrm{MPa}$ has been reported. Moreover, PEF provides a superior $\mathrm{O}_{2}$ and $\mathrm{CO}_{2}$ barrier [37,39-44]. All these features confirm their great application suitability. However, it should not be neglected that the different architecture of the furan ring, along with smaller inter-atomic distances between the carboxylate groups and non-linear structure of FDCA, significantly affect the crystallizability of furan polyesters. This is a critical issue for the production, processing, and performance of thermoplastic copolyester elastomers (TPEE), whose consumption by the processing industry is also constantly growing. The character- istic features of these materials are their strong ability for elastic deformations and good processability, what is a consequence of specific thermo-reversible multiphase structure [45]. This may be achieved by combining semicrystalline polyester rigid segments with highly flexible amorphous segments. In consequence, during cooling from the melt, the molecular interactions between the rigid segments (i.e., their crystallization) lead to the formation of crystalline nanodomains (the hard phase) surrounded by flexible segments - rich soft phase. The crystalline regions generate thermally reversible, physical network nodes that provide strength and dimensional stability to the copolymer. The amorphous soft phase, in turn, ensures the elasticity of the materials [46, 47]. Thus, the performance of thermoplastic elastomers strongly depends on two factors: the rigid and flexible segment contents, and the state of the phase separation driven by the crystallizability of the rigid block.

Recently, a few papers on the synthesis and characterization of furan-based copolyesters have been published $[39,48]$, also papers revealing the features of thermoplastic elastomers [49-51]. In our previous studies, we reported bio-based multiblock copolymers consisting of PTF as the rigid segment and dimerized fatty acid as the flexible segment (PTF-block-FADD) [44, 52]. All reagents used for the copolymer syntheses were plant-derived. The new materials containing 35 to $65 \mathrm{wt} \%$ of the furan-ester rigid segments were characterized by multiphase microstructures in which the continuous soft phase was formed by a mixture of rigid and flexible blocks, and the phase separation ensured by the presence of crystalline regions of the hard phase. The copolymers underwent melting and glass transitions, while the $T_{m}$ and $T_{g}$ values depended on the PTF to FADD segment ratio. Their mechanical behavior was typical for elastomers with deformation abilities up to $c a .410 \%$ for the sample with the highest content of fatty acids. Moreover, a rubbery plateau was observed in the $25-80{ }^{\circ} \mathrm{C}$ temperature range, which also supports their elastomeric character. However, the studies also confirmed disturbances in the crystallization process of the materials, which is particularly clear when two homopolymers: poly(trimethylene terephthalate) and poly(trimethylene 2,5-furandicarboxylate) were compared. It was evident that PTF had a much slower crystallization from melt, differences in melting enthalpies, as well as the effect of cold crystallization during heating [44]. Similar effects in PTF were also observed by other researchers [43, 53-55]. Thus, an incorporation of FADD amorphous chains between furan-ester segments hindered their crystallization even further, which did not favor the phase separation in PTF-block-FADD copolymers. For that reason, annealing seemed to be a suitable process to enhance the copolymers' crystallinity, hence the phase separation, but the physical properties also evolved.

The presented studies show the effect of thermal aging on the physical transitions and crystalline structure 
of poly(trimethylene 2,5-furandicarboxylate)-block-(fatty acid dimer diol) copolymers with different PTF to FADD ratios. The results prove an improvement in the phase separation or further crystallization and its effect on the mechanical performance of the copolymers. In other words, the mechanical properties of fully bio-based PTF-block-FADD copolymers can be tailored by thermal treatments.

\section{EXPERIMENTAL PART}

\section{Materials}

- 2,5-Furandicarboxylic acid (FDCA), $99 \%$ purity, was purchased from Intatrade Chemicals $\mathrm{GmbH}$ (Germany).

- 1,3-Propanediol (1,3-PD), Susterra ${ }^{\mathrm{TM}}$ Propanodiol, and fatty acid dimer diol (FADD), Pripol 2033, were kindly supplied by DuPont Tate \& Lyle BioProducts, and Croda (The Netherlands), respectively.

- Zinc acetate dehydrate, $\mathrm{Zn}(\mathrm{OAc})_{2^{\prime}}$ (Chempur) and tetrabutyl orthotitanate, $\mathrm{Ti}(\mathrm{OBu})_{4^{\prime}}$ (Fluka) were used as the catalysts for the materials' synthesis, whilst Irganox 1010 (Ciba-Geigy, Switzerland) was applied as an antioxidant.

\section{Preparation of PTF-block-FADD copolymers' samples}

A detailed description of the furan-based copolymers' synthesis can be found elsewhere [44, 52]. In general, the process was carried out in two steps: first a direct esterification of FDCA with 1,3-PD was conducted with a release of water as a by-product, and oligomeric PTF was synthesized. In the second step, a copolymerization of the PTF oligomers with FADD proceeded in order to form a multiblock copolymer. During this step, 1,3-PD was released as a by-product and an increase of the stirrer torque, due to the increased viscosity of the reactive mixture, was observed. For this study, PTF homopolymer, as well as copolymers containing 35, 50 and $65 \mathrm{wt} \%$ of PTF segments (denoted as PTF35, PTF50 and PTF65, respectively), were prepared. As the molecular weight of FADD was constant, the changes in the copolymer compositions were controlled via changes in the PTF segment length.

The "as-received" polymer materials were granulated and subjected to injection molding. Before processing, the materials were dried in a vacuum oven at a temperature of $60^{\circ} \mathrm{C}$ for 12 hours. The dumbbell shaped samples (ISO 37:2005 type 3) were prepared using the laboratory injection machine Boy 15 (Dr Boy GmbH \& Co.) with the following parameters: injection pressure of 40-60 MPa, melting temperature of $135-180{ }^{\circ} \mathrm{C}$ depending on specified $T_{m}$ of the material, mold temperature of $30^{\circ} \mathrm{C}$, holding pressure of $20 \mathrm{MPa}$ for $15 \mathrm{~s}$, and cooling time of $15 \mathrm{~s}$. Samples for WAXS/SAXS analysis had the form of thin films of ca. 125-130 $\mu \mathrm{m}$ prepared by compression molding (plate press, P200 E, Dr Collin $\mathrm{GmbH}$ ) at a temperature of $15^{\circ} \mathrm{C}$ higher than melting point, pressure of $1 \mathrm{MPa}$ within a time of $10 \mathrm{~s}$. The films were immediately cooled in ice water to obtain amorphous samples. Two samples were stacked together for measurements.

The effect of thermal aging was studied on both injection molded and compressed samples. The materials were subjected to thermal treatment at a temperature of $20{ }^{\circ} \mathrm{C}$ above the $T_{c c}$ (temperature of cold crystallization) for 4 hours in a vacuum oven, and then cooled freely in the air.

\section{Methods of testing}

- The melting and crystallization behavior of the copolymers was studied using differential scanning calorimetry (DSC, Q100 TA Instruments) in the heating-cooling-heating cycles. The temperature range of -60 to $200^{\circ} \mathrm{C}$ was applied.

- Wide-angle (WAXS) and small-angle X-ray scattering (SAXS) measurements were performed at the non-crystalline diffraction (NCD) beamline (BL-11) of the Alba synchrotron (Cerdanyola del Vallès, Barcelona, Spain) at a wavelength of $\lambda=0.100 \mathrm{~nm}$. X-ray scattering data were collected on a Quantum 210r CCD ADSC detector for SAXS and LX255-HS Rayonix detector for WAXS data. The $q$-axis calibration was obtained by using the following standards: silver behenate for SAXS detector and $\mathrm{Cr}_{2} \mathrm{O}_{3}$ for WAXS detector. The WAXSFIT software [56] was employed to edit and analyze the diffractograms. The crystallinity degrees, $X_{\mathrm{cWAXS}^{\prime}}$ were calculated as the ratio of crystalline peaks integrated area to total spectrum area. The Lorentz corrected SAXS data were used to calculate the long period values, $L_{p}=1 / s_{\max }$ where $s=2 \pi \sin \theta / \lambda$ is the modulus of the scattering vector and $2 \theta$ is the scattering angle.

- The mechanical behavior of the copolymers before and after annealing was studied in static tensile tests and the Shore hardness. The tensile tests were performed on a universal testing machine (Instron 5566) equipped with an optical extensometer (ISO 527-1:2012, ISO 527-2:2012). The dumbbell shaped samples were deformed at the speed of $1 \mathrm{~mm} / \mathrm{min}$ up to $1 \%$ of strain in order to calculate the tensile modulus, and then the speed was $100 \mathrm{~mm} / \mathrm{min}$. Eight tests were done for each material. The average values of tensile strength, stress at break, stress at yield (if observed), elongation at break and tensile modulus were calculated from the stress-strain curves. The hardness was measured using a Shore durometer (Zwick) scale D.

\section{RESULTS AND DISCUSSION}

As mentioned above, the furan-based polyesters, due to the specific chemical structure of the FDCA, are characterized by the relatively high stiffness of mers. This hinders the macromolecules' folding (crystallization), may affect the glass transition and surely decreases the melting point compared to terephthalic acid-based analogues. This tendency is clearly observed in the thermal 


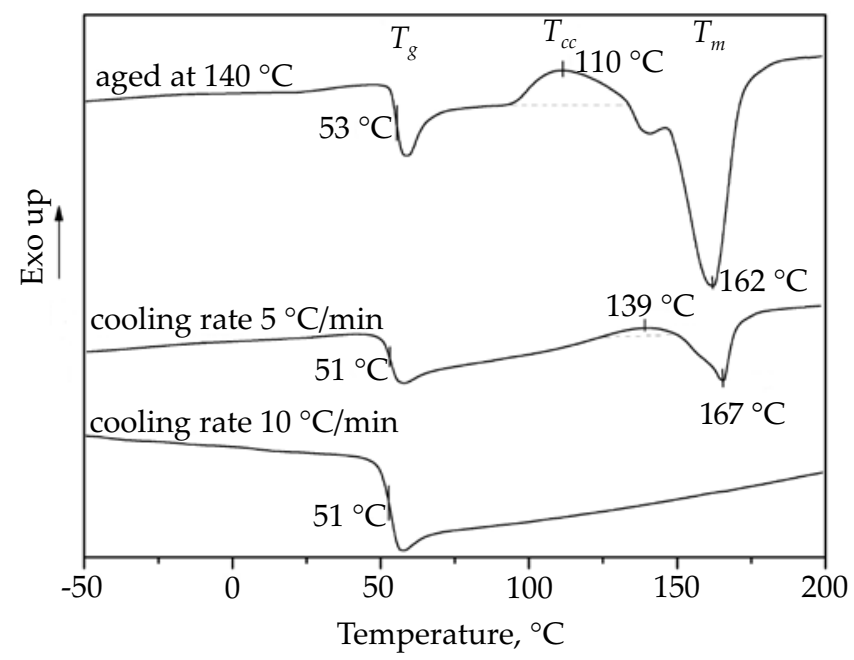

Fig. 1. DCS heating scans of PTF homopolymers after cooling at different rates: $10^{\circ} \mathrm{C} / \mathrm{min}, 5^{\circ} \mathrm{C} / \mathrm{min}$, and after aging at $140{ }^{\circ} \mathrm{C}$

behavior of PTF homopolymers using DSC analysis with different cooling rates (Fig. 1).

The "as-received" sample, after cooling from melt with the standard rate of $10^{\circ} \mathrm{C} / \mathrm{min}$, was amorphous with a clear glass transition effect at $51{ }^{\circ} \mathrm{C}$. When the cooling rate
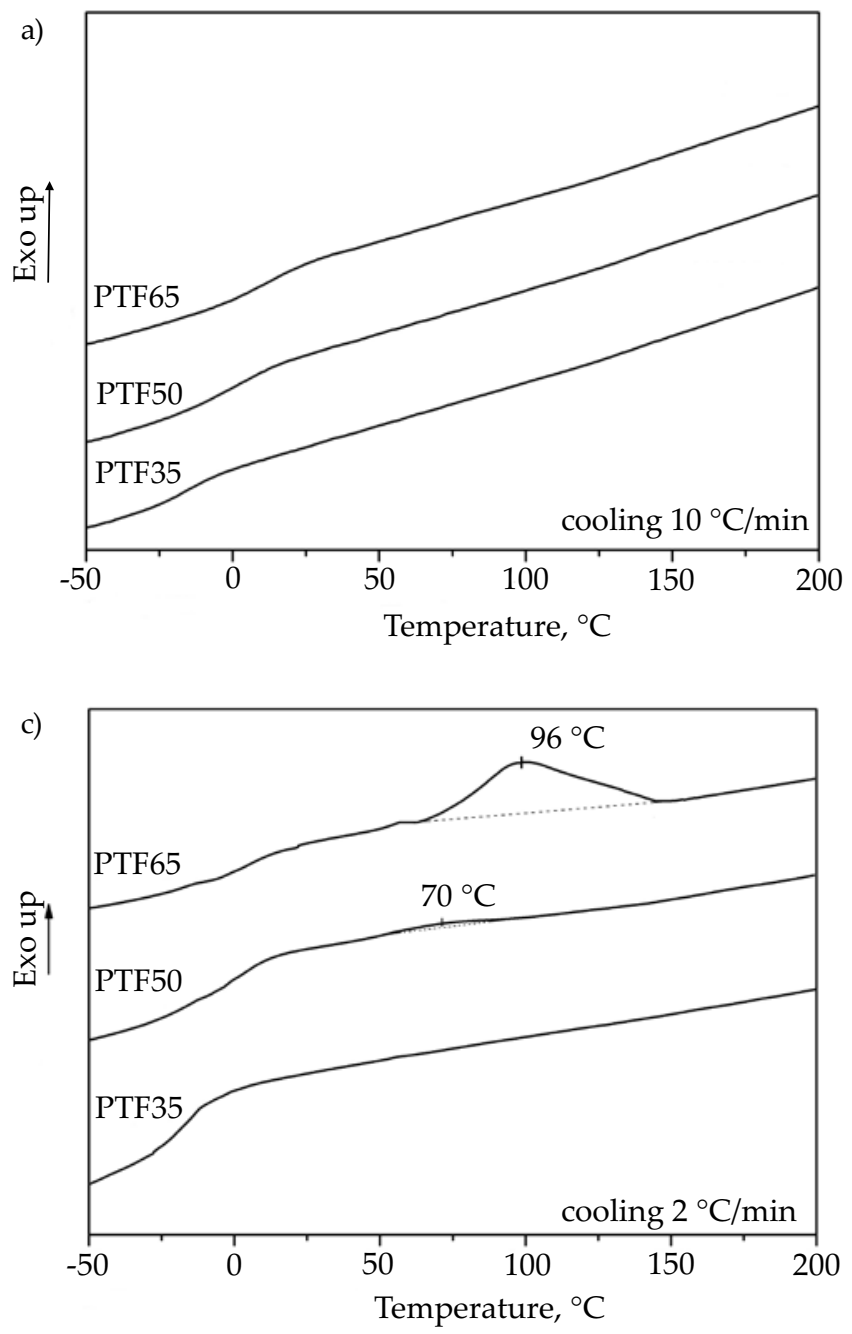

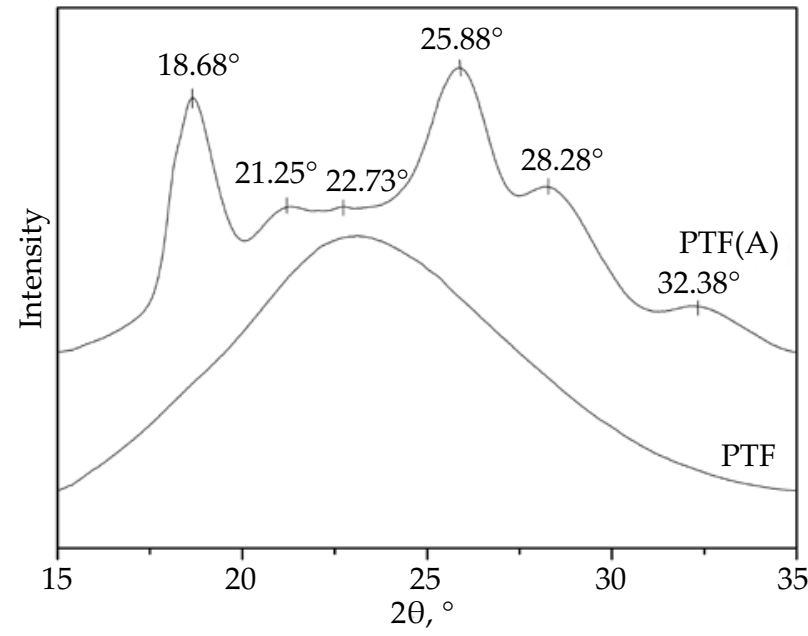

Fig. 2. WAXS spectra of PTF sample "as-received" and aged at $140{ }^{\circ} \mathrm{C}$

was reduced to $5^{\circ} \mathrm{C} / \mathrm{min}$, a small crystallization peak appeared at $120^{\circ} \mathrm{C}\left(\Delta H_{c}=0.5 \mathrm{~J} / \mathrm{g}\right)$, and during the $2^{\text {nd }}$ heating, when the glass transition is exceeded, a small exothermic effect with a maximum at $139{ }^{\circ} \mathrm{C}$ was observed, ascribed to the cold crystallization. Then, this effect smoothly
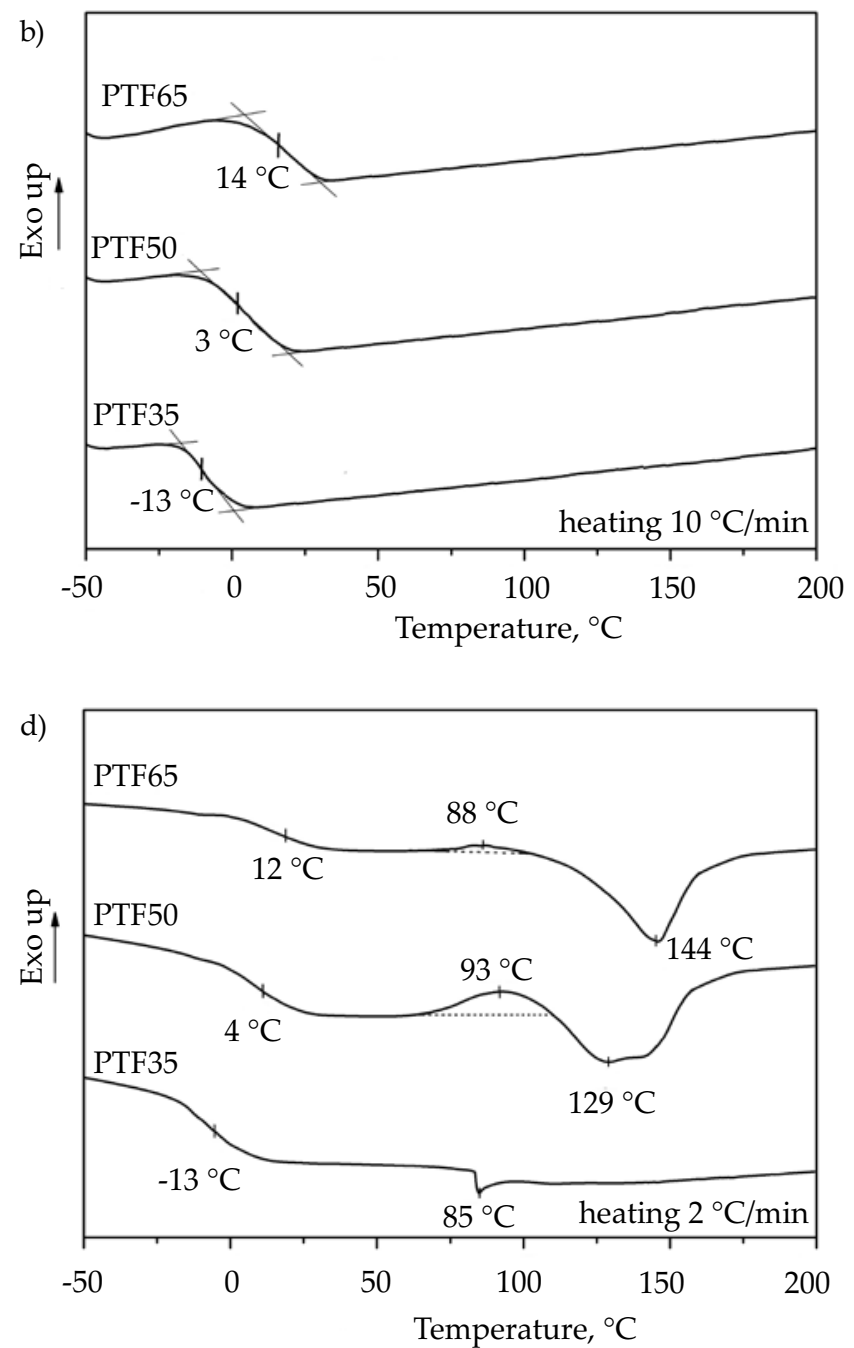

Fig. 3. The DSC cooling $/ 2^{\text {nd }}$ heating thermograms of PTF-block-FADD copolymers with a cooling rate from melt of: a, b) $10{ }^{\circ} \mathrm{C} / \mathrm{min}$, c, d) $2{ }^{\circ} \mathrm{C} / \mathrm{min}$ 
transmuted into an endothermic one $\left(\Delta H_{m}=5.1 \mathrm{~J} / \mathrm{g}\right)$ determining the polymer melting at $167^{\circ} \mathrm{C}$. Such behavior confirms that the material is able to crystallize, however the difference between the $T_{m}$ and $T_{c}$ indicates that $c a .47 \mathrm{de}-$ grees of supercooling is needed to initiate the crystallization. If, however, the sample is subjected to annealing at the temperature of $T_{c c^{\prime}}$ the enhanced macromolecular mobility leads to re-organization in the crystalline structure. This effect is clear by a significant increase of the melting enthalpy $\left(\Delta H_{m}=30 \mathrm{~J} / \mathrm{g}\right)$, thus crystallinity degree. The melting multipeak appears due to the presence of the secondary crystallites, as well as a slight increase in $T_{g}$ value observed as a consequence of better macromolecule packing. These structural changes in PTF due to thermal aging are in accordance with the studies of Vannini et al. [55], who also reported an enormous improvement in oxygen and water vapor barrier effect resulting from the crystalline region development and decreasing free volume. Moreover, the DSC scan of the annealed sample revealed the effect of a single, endothermic, physical aging peak in the $T_{g}$ region. Such an effect, studied in detail for amorphous and semicrystalline PET samples subjected to annealing at different temperatures and durations [57], was also observed for annealed poly(butylene 2,5-furanoate) and its copolymers [42]. This effect is related to the character of the amorphous phase depending on its distance from the crystalline region. In other words, the crystallites in the immediate vicinity constrain the amorphous phase whose mobility is reduced when compared to the mobility of the phase in fully amorphous samples. This effect results in a slightly increased $T_{g}$ value and enhanced DSC response at the glass transition region. Other evidence for the development of the crystalline structure due to the thermal treatment is provided by the WAXS spectra of "as-received" and aged at $140{ }^{\circ} \mathrm{C}$ PTF samples (Fig. 2).

The most intense peaks at $18.68,21.25$ and $25.88^{\circ}$ of $2 \theta$, recorded for the annealed sample, are very close to those reported in the literature [53,55], and the mass crystallinity degree calculated from WAXS is $49 \%$.

When applying the standard cooling/heating rate to analyze the thermal properties of the PTF-block-FADD copolymers, the materials do not reveal any effects of crystallization during cooling nor melting enthalpies during $2^{\text {nd }}$ heating (Figs. 3a, 3b).

In DSC thermograms, only clear glass transition effects are observed, and $T_{g}$ values are lowered with fewer fatty acids segments. It can be concluded that, in the copolymers' microstructure, only one continuous soft phase is formed or the content of the crystalline hard phase domains are too small to be detected by DSC. Thus, the phase separation does not exist for the samples cooled with the rate of $10^{\circ} \mathrm{C} / \mathrm{min}$.

Reducing the cooling rate to $2{ }^{\circ} \mathrm{C} / \mathrm{min}$ enables the crystallization process as evidenced by the thermograms in Figs. 3c, 3d. This is clearly observed for the PTF65 sample, which reveals an exothermal peak. For the PTF50 copolymer, the crystallization peak is smaller, thus the nucle-

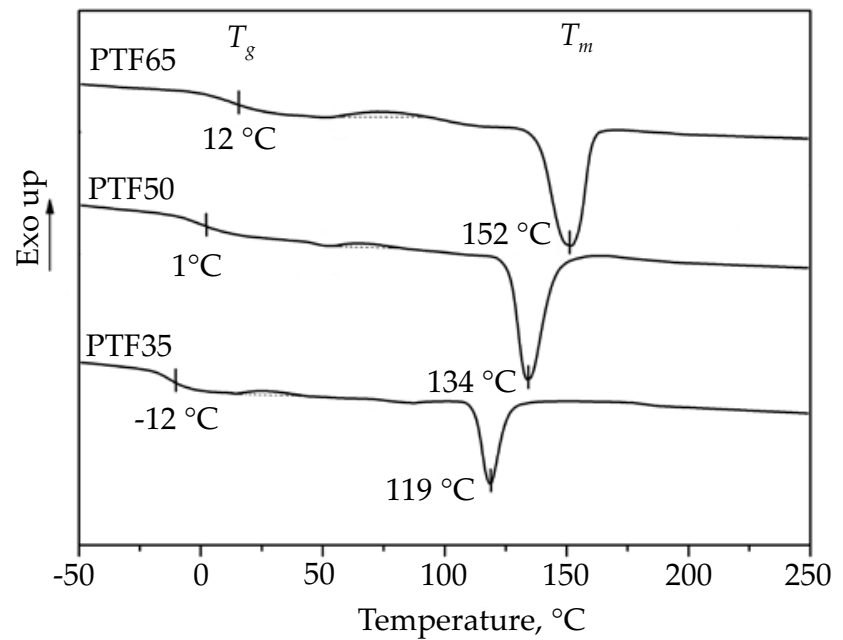

Fig. 4. DSC thermograms of PTF-block-FADD copolymers after annealing, $1^{\text {st }}$ heating with the rate of $10{ }^{\circ} \mathrm{C} / \mathrm{min}$ [44]

ation process is initiated. However, the crystals' growth is impeded by the glass transition. In consequence, the microstructure is unstable and, when subjected to a $2^{\text {nd }}$ heating cycle, the cold crystallization proceeds after that $T_{g}$ is exceeded. The melting peaks observed in both cases confirm the presence of crystalline domains in the hard phase. For the copolymer containing the smallest content of PTF segments, although the crystallization peak during cooling is not observed, the presence of a small endothermic effect during the $2^{\text {nd }}$ heating indicates its ability to crystallize. However, the crystalline structure is rather fine and imperfect. It is worth noting that similar observations on the nucleating effect of the flexible segments modification of PTF were reported in a US patent [54] wherein a significant increase of PTF melting enthalpy was observed for contents with up to $50 \mathrm{wt} \%$ of poly(trimethylene ether) glycol. However, since the phase separation forced by the rigid segment crystallization is a key feature of TPEE and the presence of cold crystallization peaks suggests that the copolymers are still in thermodynamic nonequilibrium, the copolymer samples were subjected to aging at the temperature of $20{ }^{\circ} \mathrm{C}$ above a detected or expected $T_{c c^{\prime}}$ i.e., $105{ }^{\circ} \mathrm{C}$ for PTF65, $115{ }^{\circ} \mathrm{C}$ for PTF50, and $80{ }^{\circ} \mathrm{C}$ for PTF35. All the

T a b l e 1. Thermal and crystal structure parameters for unaged and thermally aged (A) PTF-block-FADD samples

\begin{tabular}{c|c|c|c}
\hline Sample & $T_{m^{\prime}}{ }^{\circ} \mathrm{C}$ & $X_{c \mathrm{WAXS}^{\prime}} \%$ & $L_{p^{\prime}} \mathrm{nm}$ \\
\hline PTF & 167 & 1 & - \\
PTF65 & 144 & 19 & 6.3 \\
PTF50 & 129 & 9 & 5.4 \\
PTF35 & 85 & 7 & 5.7 \\
PTF(A) & 162 & 49 & - \\
PTF65(A) & 152 & 35 & 13.3 \\
PTF50(A) & 134 & 37 & 11.8 \\
PTF35(A) & 119 & 23 & 9.1 \\
\hline
\end{tabular}




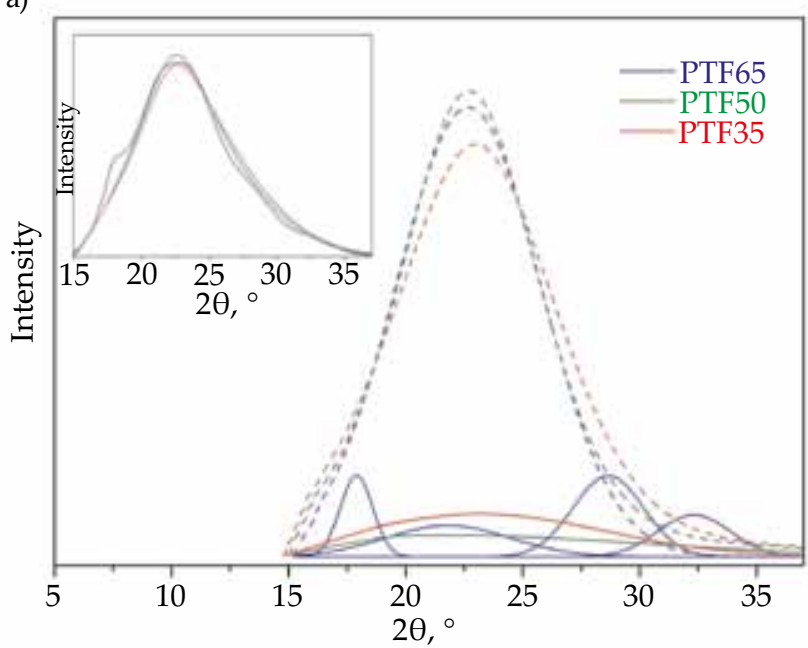

b)

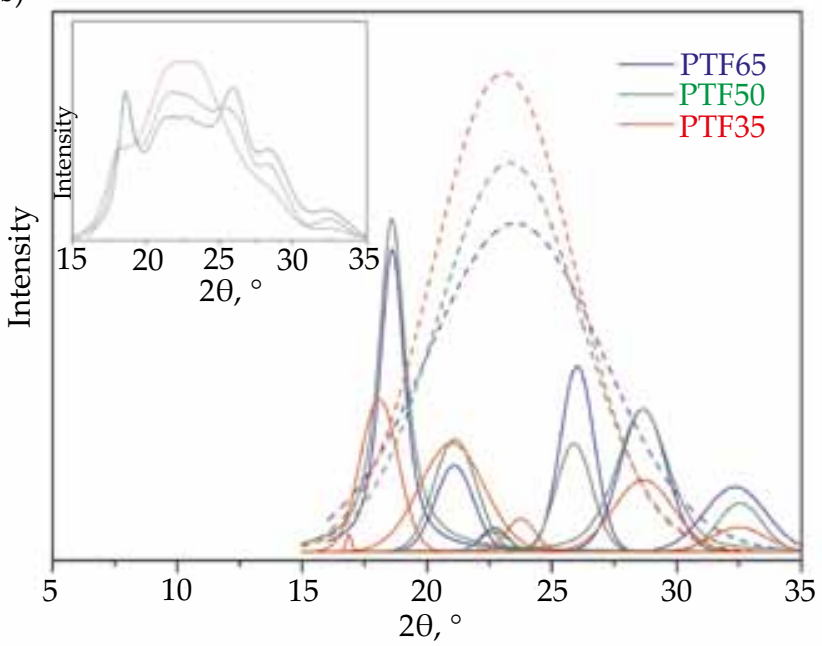

Fig. 5. WAXS analysis of PTF-block-FADD copolymers: a) before, b) after thermal aging

samples became opaque during annealing, but did not suffer deformation or melting.

The DSC thermograms in Fig. 4 presented and discussed widely in [44], confirm significant changes in the copolymers' microstructure. All materials reveal multiphase structures with clear melting enthalpies, whose maxima $\left(T_{m}\right)$ are extended to higher temperatures compared to the non-annealed samples. At the same time, the $T_{g}$ values correspond to the values determined in Fig. 3.

Wide-angle X-ray diffraction analysis of the copolymer structures indicates that, although the materials crystallize slowly, the film samples prepared by compression molding are not completely amorphous (Fig. 5a).

The copolymers' samples are characterized by relatively small crystallinity degree, but higher than for PTF homopolymer (Table 1). It proves that if the materials are not in equilibrium after processing they crystallize during storage. In fact, when stored at ambient temperatures, all copolymers are above their $T_{g}$. An incorporation of more flexible fatty acids segments among the rigid PTF blocks enlarges the distances between furan rings providing higher flexibility to the whole macromolecules. That fa-

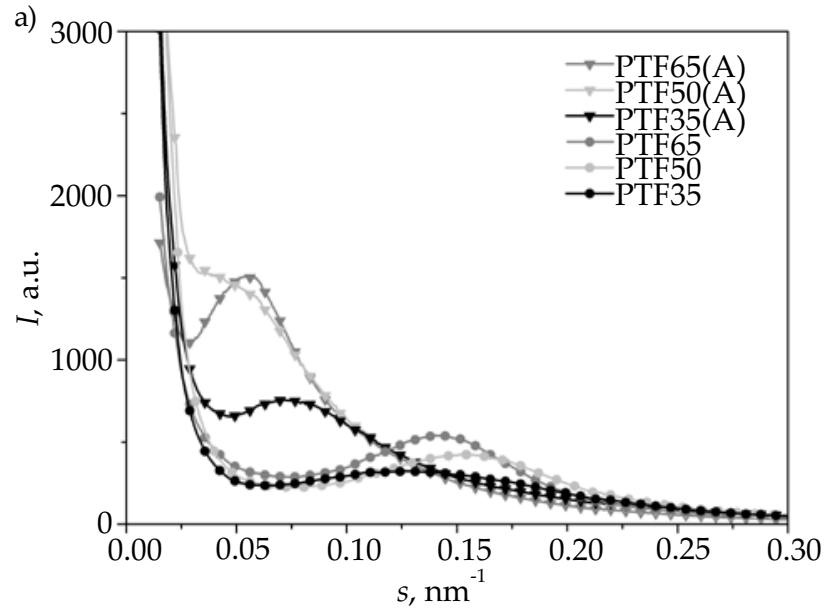

vors their mobility and folding. Nevertheless, a significant development in the crystalline structure of the copolymers is achieved due to thermal aging (Fig. 5b). The main reflections superimposed over the halo of the amorphous phase strongly correspond to the reflection positions detected for semicrystalline PTF. It confirms that only the furan-based rigid segment is able to crystallize and the FADD segments are fully involved in the soft phase formation. The crystallinity degrees calculated from WAXS spectra (Table 1) are improved and evidently increase along with the content of PTF rigid segments in the copolymer compositions.

Changes in the crystalline nanodomain sizes are also observed in the small-angle X-ray scattering (SAXS) analyses. Figure 6 presents the raw SAXS data recorded for both thermally treated and untreated samples (Fig. 6a), and the data after the Lorentz correction in order to emphasize the interlamellar distances (Fig. 6b). Significant differences in the shape of the curves were observed; specifically, the scattering power is much poorer for the "as-received" films whilst the characteristics of the annealed samples revealed clear maxima at low values of

b)

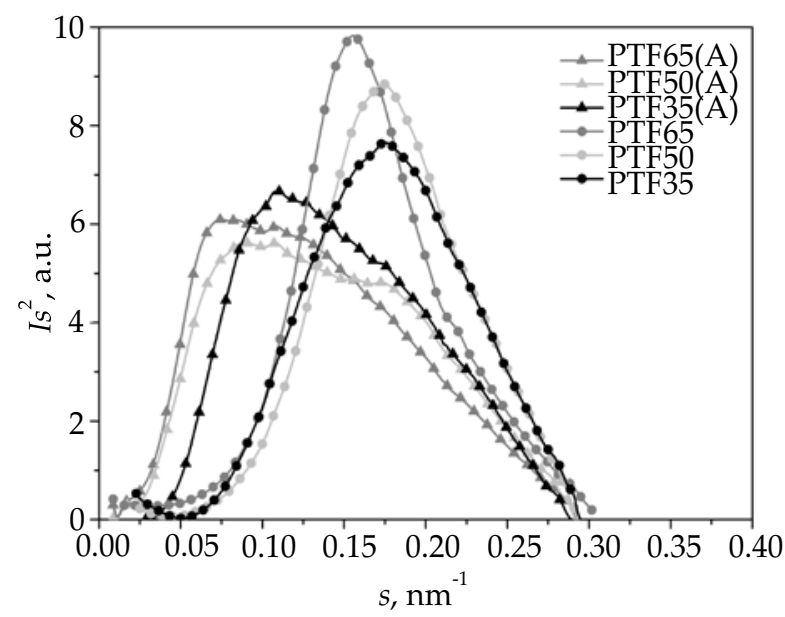

Fig. 6. SAXS data analysis: a) raw data, b) after Lorentz correction at $23{ }^{\circ} \mathrm{C}$ 
T a b l e 2. Mechanical parameters for PTF and copolymers before and after annealing

\begin{tabular}{|c|c|c|c|c|c|c|}
\hline Sample & $R_{m^{\prime}} \mathrm{MPa}$ & $\sigma_{b^{\prime}} \mathrm{MPa}$ & $\varepsilon_{b^{\prime}} \%$ & $E, \mathrm{MPa}$ & $H$, ShD & Reference \\
\hline PTF & $74.29 \pm 3.11$ & $74.29 \pm 3.11$ & $4.1 \pm 0.8$ & $1929 \pm 121$ & $83 \pm 1$ & [44] \\
\hline $\operatorname{PTF}(\mathrm{A})$ & $53.32 \pm 4.23$ & $53.32 \pm 4.23$ & $2.6 \pm 0.6$ & $2455 \pm 195$ & $86 \pm 1$ & this study \\
\hline PTF65 & $15.06 \pm 0.63$ & $15.00 \pm 0.58$ & $314 \pm 27$ & $144 \pm 21$ & $63 \pm 1$ & [44] \\
\hline PTF65(A) & $26.20 \pm 0.47$ & $16.30 \pm 1.12$ & $138 \pm 21$ & $277 \pm 25$ & $67 \pm 1$ & this study \\
\hline PTF50 & $10.44 \pm 0.33$ & $10.20 \pm 0.40$ & $305 \pm 33$ & $30 \pm 8$ & $54 \pm 1$ & [44] \\
\hline PTF50(A) & $16.03 \pm 0.17$ & $14.09 \pm 0.26$ & $212 \pm 10$ & $108 \pm 11$ & $56 \pm 1$ & this study \\
\hline PTF35 & $8.75 \pm 0.29$ & $8.48 \pm 0.29$ & $411 \pm 7$ & $8 \pm 1$ & $43 \pm 1$ & [44] \\
\hline PTF35(A) & $8.95 \pm 0.20$ & $8.48 \pm 0.20$ & $238 \pm 29$ & $32 \pm 3$ & $43 \pm 1$ & this study \\
\hline
\end{tabular}

$R_{m}$ - tensile strength, $\sigma_{b}$ - stress at break, $\varepsilon_{b}$ - elongation at break, $E$ - tensile modulus, $H$ - Shore D hardness.

the modulus of scattering vector $s$ (Fig. 6a). The maxima pronounced by the Lorentz correction determined the so-called long period values, $L_{p}$ (Fig. 6b). This parameter is interpreted as a sum of the average thickness of the crystalline lamella and the amorphous regions in the material structure. On the one hand, the presence of peaks confirms once again that the crystalline lamellae exist in unaged samples. However, the $L_{p}$ values are relatively small (of ca. $6.5 \mathrm{~nm}$ ) and do not differ with PTF segment content (Table 1). This may support the assumption about the materials cold crystallization during storage. On the other hand, the annealing process results in a significant increase of $L_{p}$ values, almost two-fold for PTF65 and PTF50 copolymers, but the peaks are broader and less intense compared to unaged samples. This suggests that, during annealing, the crystallization process continued to expand the existing crystallites and it is favored in copolymers containing a relatively high content of rigid segments. As a consequence, the lamellae thickness increased, as well as the $L_{p}$ values. It is also possible that, as a result of the re-organization, secondary crystallites with different morphologies were formed resulting in more extensive peaks. This is not, however, supported by DSC results since only single melting peaks are observed for the aged copolymer samples. Even if the character of the crystalline structure after re-organization is

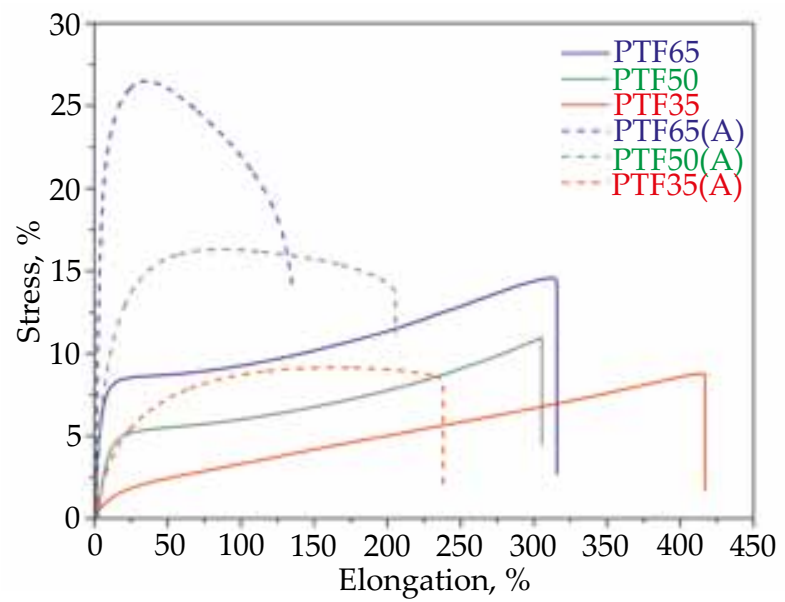

Fig. 7. The representative stress-strain characteristics of PTF-block-FADD before and after thermal aging not strictly recognized, it apparently affects the mechanical performance of the copolymers.

The stress-strain characteristics of the static tensile tests done before and after thermal aging are presented in Fig. 7 and Table 2. The curves received for "as injection molded" samples, discussed in details in [44], correspond to typical elastomer curves with the level of stress and strain dependent on the PTF to FADD segment ratios. In other words, an increasing content of the amorphous blocks and relatively low crystallinity improves deformation ability of the copolymers. The annealing process significantly changes the mechanical behavior of the samples resulting in higher tensile strengths $\left(R_{m}\right)$ but reducing elongation at break values $\left(\varepsilon_{b}\right)$. Moreover, a clear necking and typical plastic deformation are observed on the tensile curves. These findings support the previous DSC analysis conclusions about the slow crystallization rate of the furan copolyesters. It is crucial when the processing of the polymers is considered. In the case of injection molding, a cooling rate is relatively high and a polymer/copolymer is unable fully to crystallize but the existing microstructure ensures a rubber-like behavior. An improvement in the phase separation due to further crystallization, in turn, constrains the continuous soft phase, which does not favor the elastic properties of the copolymers. Materials gain in stiffness but lose the ability for high deformations. These effects are also supported by the hardness measurements (Table 2). An increase in $H$ values is observed for almost all annealed copolymers except the sample with the smallest PTF content (the least crystalline). This leads to the conclusion that the mechanical performance of the fully bio-based PTF-block-FADD copolymers is tunable and may be tailored as needed not only by the PTF to FADD segment ratio but also the appropriate processing conditions or possibly the thermal treatment.

\section{CONCLUSIONS}

In this study, the effect of thermal aging on the physical transitions, crystalline structure development, and the mechanical performance of fully bio-based PTF-block-FADD copolymers was studied. Although the materials 
crystallize slowly due to the stiffening effect of the furanoate units, they are semicrystalline in their nature. Their mechanical performance strongly depends on the state of the microstructure, and the resulting microstructure is affected by the thermal treatment of the sample. When subjected to thermal processing and cooled from melt quite fast the microstructure is characterized by rather poor phase separation. In consequence the copolymers, depending on PTF to FADD segment ratio, reveal elastomeric behavior and rubbery plateaus over a relatively large temperature range. If, however, they are subjected to annealing above $T_{c c^{\prime}}$ an improvement in the phase separation due to further crystallization leads to an increase of the tensile strength and hardness but at the cost of reducing elongation at break and ability to deformation. The changes in the crystalline structures were confirmed by DSC, WAXS and SAXS analyses. All these observations lead to the conclusion that, by changing the copolymer composition or employing thermal aging, it is possible to fit the PTF-block-FADD performance to a broad range of possible applications both as thermoplastic elastomers and engineering materials for precisely molded parts.

\section{ACKNOWLEDGMENTS}

The synchrotron experiments were performed at beamline BL11-NCD at ALBA Synchrotron Light Facility (proposal no. 2015021187) with the collaboration of ALBA staff. The studies were partly financed by National Science Center, Poland within the project no. 2017/01/X/ST8/00031 (MINIATURA 1). Miss Kowalczyk also would like to thank for financial support from West Pomeranian University of Technology (Dean's grant for young scientists).

\section{REFERENCES}

[1] Duda A., Penczek S.: Polimery 2003, 48, 16.

[2] "Poly(Lactic Acid): Synthesis, Structures, Properties, Processing, and Applications", (Eds. Auras R., Lim L.-T., Selke S., Tsuji H.), Wiley \& Sons, New Jersey 2010.

[3] Lotz B.: "Advances in Polymer Science: Crystal Polymorphism and Morphology of Polylactides", (Eds. Di Lorenzo M., Androsch R.), Vol. 279, Springer, Cham 2017.

[4] Fujimaki T.: Polymer Degradation and Stability 1998, 59, 209. http://dx.doi.org/10.1016/S0141-3910(97)00220-6

[5] Terzopoulou Z.N., Papageorgiou G.Z., Papadopoulou E. et al.: Polymer Composites 2016, 37, 407. http://dx.doi.org/10.1002/pc.23194

[6] Xu J., Guo B.-H.: Biotechnology Journal 2010, 5, 1149. http://dx.doi.org/10.1002/biot.201000136

[7] Jacquel N., Freyermouth F., Fenouillot F. et al:: Journal of Polymer Science Part A: Polymer Chemistry 2011, 49, 5301. http://dx.doi.org/10.1002/pola.25009

[8] Siegenthaler K.O., Künkel A., Skupin G., Yamamoto M.: "Synthetic Biodegradable Polymers", (Eds.
Rieger B., Künkel A., Coates W.G., Reichardt R., Dinjus E., Zevaco A.T.), Springer, Berlin Heidelberg 2012, p. 91.

[9] Müller R.-J., Witt U., Rantze E., Deckwer W.-D.: Polymer Degradation and Stability 1998, 59, 203. http://dx.doi.org/10.1016/S0141-3910(97)00186-9

[10] Weng Y.-X., Jin Y.-J., Meng Q.-Y. et al.: Polymer Testing 2013, 32, 918. http://dx.doi.org/10.1016/j.polymertesting.2013.05.001

[11] Zehetmeyer G., Meira S., Scheibel J.-M. et al.: Polymer Bulletin 2017, 74, 3243. http://dx.doi.org/10.1007/s00289-016-1896-8

[12] Hassan M.-A., Yee L.-N., Yee P.-L. et al.: Biomass and Bioenergy 2013, 50, 1.

http://dx.doi.org/10.1016/j.biombioe.2012.10.014

[13] Bugnicourt E., Cinelli P., Lazzeri A. et al.: Express Polymer Letters 2014, 8, 791. http://dx.doi.org/10.3144/expresspolymlett.2014.82

[14] Lau N.-S., Ch'ng D., Chia K.-H. et al.: Journal of Biobased Materials and Bioenergy 2014, 8, 118. http://dx.doi.org/10.1166/jbmb.2014.1418

[15] Oladipo A.A., Abureesh M.A., Gazi M.: International Journal of Biological Macromolecules 2016, 89, 161.

[16] Jang G.-W., Wong J.-J., Huang Y.-T., Li C.-L.: “Ionic Liquids in the Biorefinery Concept: Challenges and Perspectives; Synthesis of HMF in Ionic Liquids: Biomass-Derived Products", (Ed. Bogel-Lukasik R.), RSC Green Chemistry 2016, p. 202.

[17] Kowalczyk I., Kwiatkowska M., Rosłaniec Z.: Elastomery 2016, 20, 40.

[18] Kröger M., Prüße U., Vorlop K.-D.: Topics in Catalysis 2000, 13, 237.

[19] Pat. EU EP0356703A3 (1990).

[20] Pat. US 8748637B2 (2013).

[21] Pat. WO 2010132740 (2013).

[22] Pat. WO 2 011/043 660 (2013).

[23] Zhang Z., Deng K.: ACS Catalysis 2015, 5, 6529. http://dx.doi.org/10.1021/acscatal.5b01491

[24] Zhang S., Zhang L.: Polish Journal of Chemical Techno$\log y$ 2017, 19, 11. http://dx.doi.org/10.1515/pjct-2017-0002

[25] Banerjee A., Dick G.R., Yoshin T., Kanan M.W.: Nature 2016, 531, 215. http://dx.doi.org/10.1038/nature17185

[26] Scott A.: Chemical and Engineering News 2016, 94, 15.

[27] Boufi S., Gandini A., Belgacem M.N.: Polymer 1995, $36,1689$. http://dx.doi.org/10.1016/0032-3861(95)99015-M

[28] Zhang L., Luo Q., Qin Y., Yebo L.: RSC Advances 2017, 7,37 . http://dx.doi.org/10.1039/C6RA25045A

[29] Cao M., Zhang C., He B. et al.: Macromolecular Research 2017, 25, 722 . http://dx.doi.org/10.1007/s13233-017-5070-4

[30] Cousin T., Galy J., Roussea A. et al.: Journal of Applied Polymer Science 2018, 135, 45901. http://dx.doi.org/10.1002/app.45901 
[31] Jiang Y., Maniar D., Woortman A.J.J. et al.: RSC Advances 2016, 6, 67941. http://dx.doi.org/10.1039/C6RA14585J

[32] Hong S., Min K.-D., Nam B.-U. et al.: Green Chemistry 2016, 18, 5142. http://dx.doi.org/10.1039/C6GC01060A

[33] Sousa A.F., Fonseca A.C., Serra A.C. et al.: Polymer Chemistry 2016, 7, 1049. http://dx.doi.org/10.1039/C5PY01702E

[34] Sousa A.F., Coelho J.F.J., Silvestre A.J.D.: Polymer 2016, 98, 129. http://dx.doi.org/10.1016/j.polymer.2016.06.015

[35] Tsanaktsis V., Terzopoulou Z., Nerantzaki M. et al.: Materials Letters 2016, 178, 64. http://dx.doi.org/10.1016/j.matlet.2016.04.183

[36] Papageorgiou G.Z., Papageorgiou D.G., Terzopoulou Z. et al.: European Polymer Journal 2016, 83, 202. http://dx.doi.org/10.1016/j.eurpolymj.2016.08.004

[37] Wang J., Liu X., Zhang Y. et al.: Polymer 2016, 103, 1. http://dx.doi.org/10.1016/j.polymer.2016.09.030

[38] Soccio M., Martínez-Tong D.E., Alegría A. et al.: Polymer 2017, 128, 24. http://dx.doi.org/10.1016/j.polymer.2017.09.007

[39] Wang G., Jiang M., Zhang Q. et al.: Polymer Degradation and Stability 2017, 144, 121.

http://dx.doi.org/10.1016/j.polymdegradstab.2017.07.032

[40] Knoop R.J.I., Vogelzang W., van Haver J. et al.: Journal of Polymer Science Part A: Polymer Chemistry 2013, 51, 4191. http://dx.doi.org/10.1002/pola.26833

[41] Wu B., Xu Y., Bu Z. et al.: Polymer 2014, 55, 3648. http://dx.doi.org/10.1016/j.polymer.2014.06.052

[42] Kwiatkowska M., Kowalczyk I., Kwiatkowski K. et al.: Polymer 2017, 130, 26. http://dx.doi.org/10.1016/j.polymer.2017.10.009

[43] Jiang M., Liu Q., Zhang Q. et al.: Journal of Polymer Science Part A: Polymer Chemistry 2012, 50, 1026. http://dx.doi.org/10.1002/pola.25859
[44] Kwiatkowska M., Kowalczyk I., Kwiatkowski K., Rosłaniec Z.: Polymer 2016, 99, 503. http://dx.doi.org/10.1016/j.polymer.2016.07.060

[45] "Handbook of Thermoplastic Polyesters", (Ed. Fakirov S.), Wiley-Vch, Weinheim 2002.

[46] Holden G., Bishop E.T., Legge N.R.: “Thermoplastic Elastomers”, Hanser Publishers, Munich 1996.

[47] Djonlagic J., Nikolic M.S.: "Handbook of Engineering and Speciality Thermoplastics; Thermoplastic Copolyester Elastomers", (Eds. Thomas S., Visakh P.M.), John Wiley \& Sons, Inc., Hoboken 2011, p. 377.

[48] Terzopoulou Z., Tsanaktsis V., Bikiaris D.N. et al.: RSC Advances 2016, 6, 84003. http://dx.doi.org/10.1039/C6RA15994J

[49] Soccio M., Costa M., Lotti N. et al.: European Polymer Journal 2016, 81, 397. http://dx.doi.org/10.1016/j.eurpolymj.2016.06.022

[50] Zhou W., Zhang Y., Xu Y. et al.: Polymer Degradation and Stability 2014, 109, 21.

http://dx.doi.org/10.1016/j.polymdegradstab.2014.06.018

[51] Zheng M.Y., Zang X.L., Wang G.X. et al.: Express Polymer Letters 2017, 8, 611. http://dx.doi.org/10.3144/expresspolymlett.2017.59

[52] Kwiatkowska M., Kowalczyk I., Kwiatkowski K.: Inżynieria Materiałowa 2015, 6, 548.

[53] Papageorgiou G.Z., Papageorgiou D.G., Tsanaktsis V. et al.: Polymer 2015, 62, 28. http://dx.doi.org/10.1016/j.polymer.2015.01.080

[54] Pat. US 2016/0 312001 A1 (2016).

[55] Vannini M., Marchese P., Celli A. et al.: Green Chemistry 2015, 17, 4162. http://dx.doi.org/10.1039/C5GC00991J

[56] RabiejM.:Journal of Applied Crystallography 2014,47,1502. http://dx.doi.org/10.1107/S1600576714014782

[57] Zhao J., Wang J., Li C. et al.: Macromolecules 2002, 35, 3097. http://dx.doi.org/10.1021/ma011333z

Received 13 I 2018

\section{Rapid Communications}

Przypominamy P.T. Autorom, że publikujemy artykuły typu Rapid Communications. Prace oryginalne wyłącznie w języku angielskim o objętości $4-5$ stron maszynopisu z podwójną interlinią (plus ewentualnie 2-3 rysunki lub 1-2 tabele), którym umożliwiamy szybką ścieżkę druku (ok. 4 miesiące od chwili ich otrzymania przez Redakcję). Artykuł należy przygotować wg wytycznych zamieszczonych we wskazówkach dla Autorów. 